\title{
THE STATUS OF AGRICULTURAL FINANCING BY COMMERCIAL BANKS IN ZIMBABWE
}

\author{
${ }^{1}$ Blessing Ropafadzo Chigunhah, ${ }^{2}$ Ezekia Svotwa, ${ }^{3}$ Tendai J. Mabvure, ${ }^{4}$ Gerald Munyoro, \\ and ${ }^{5}$ Lovemore Chikazhe
}

${ }^{1}$ Graduate Business School, Chinhoyi University of Technology, Zimbabwe

${ }^{2}$ Department of Crop Science and Post-Harvest Technology, Chinhoyi University of Technology, Zimbabwe

${ }^{3}$ Department of Accounting and Finance, Chinhoyi University of Technology

${ }^{4}$ Graduate Business School, Chinhoyi University of Technology, Zimbabwe

${ }^{5}$ Department of Marketing, Chinhoyi University of Technology, Zimbabwe

\author{
${ }^{1}$ blessingmhere@gmail.com \\ 2esvotwa2@gmail.com \\ 3jmabvure@cut.ac.zw \\ ${ }^{4}$ geraldmunyoro@hotmail.com \\ ${ }^{5}$ chikazhelb@gmail.com
}

\begin{abstract}
Agricultural finance is indispensable for enhancing productive capacity in both small-scale and commercial farming. This study sought to establish the current status of agricultural financing by 12 registered and operational commercial banks in Zimbabwe in the year 2019. Questionnaires and interview guides were used to collect data. SPSS and NVivo were used for data analysis. All the commercial banks participated in agricultural financing with an average agricultural loan portfolio of $30 \%$. However, their participation in agricultural lending is yet to reach the pre-land reform maximum of 91.3\% attained in 1999. Land tenure and weather risks, as well as lack of collateral among farmers reduced the banks' appetite for lending to the agricultural sector. The majority of the commercial banks offered value chain finance, invoice finance, overdraft facilities, and term loans to agricultural sector clients that mainly included; suppliers, medium-scale, and large-scale commercial farmers. The study established a mismatch in the demand and supply of loans in the medium to long term tenure range of 1 to more than 3 years. There was low demand for 1-3-year tenure loans according to the commercial banks, and a corresponding deficit in the supply of highly demanded longer-term loans of more than 3 years for capital expenditure (CAPEX). Therefore, government should aim to; stabilize currency; arrest hyperinflation; restore economic stability; address land tenure to ensure the bankability of the 99-year Lease; and create an environment that is conducive for investment in climate and weather resilience infrastructure. Local farmers should also invest in human and physical capital to improve their access to bank credit.
\end{abstract}

Keywords: agricultural financing, capital formation, collateral, risk, term loans

(JEL Classification: Q14)

\section{BACKGROUND}

Agriculture is the largest sector in developing countries that is capable of generating the savings mass required for capital investments in other economic sectors to stimulate economic growth (Anríquez and Stamoulis 2007). However, early classical theory advocated for the reallocation of factors of production from such primary sectors that are characterized by low productivity, traditional technology and decreasing returns, to modern industrial sectors like manufacturing and services with higher productivity and increasing returns (Adelman, 2001). Agriculture was thus branded as a passive contributor to development, which did not deserve investment (Huang and Ma 2010). By neglecting agricultural sector investments, several countries like Argentina, Mexico, Nigeria, and the former Soviet Union encountered slowed development and failure in the long-run (Timmer, 1988). On the contrary, Japan, China and Korea registered growth and 
entered the ranks of developed nations by heavily investing towards agricultural development (Huang and Ma 2010). Intense investments in agriculture by African countries like Burkina Faso, Rwanda, Kenya, Cote d'Ivore, Ghana and Ethiopia also triggered productivity increases in existing farms by $6 \%$ annually, and average annual GDP growth in excess of 4\% (Alliance for Green Revolution in Africa (AGRA), 2018). Hence, according to AGRA (2017), no region in the world has successfully developed a diverse, modern economy without initially establishing a successful foundation in agriculture.

Agricultural economists consequently shifted their attention towards the role of agriculture in rural development, where the majority entirely rely on agriculture for livelihoods (Diao, Hazell and Thurlow 2010). Besides, several world development bodies are now advocating for increased financial investments in the agricultural sector. The World Bank (2015) declared the need for $\$ 80$ billion annually in developing countries to eradicate poverty, whilst AGRA (2018) proposed that US\$30 to US\$40 billion is required annually over the next decade to transform African agriculture and create vibrancy. However, only $1 \%$ of commercial lending is earmarked for the agricultural sector in developing countries (International Finance Corporation (IFC), 2014). Moreover, only a quarter of loans advanced in Africa, south of the Sahara, originated from a bank (Fan et al. 2013). Agricultural financing challenges are also rife in Zimbabwe, a landlocked country that depends on primary economic activities like agriculture and mining (United Nations, 2014). Despite being central to livelihoods and the economic progress of the nation at large, the Zimbabwean agricultural sector faces financing challenges, particularly access to bank credit. When the potential demand for credit in agricultural projects was between US $\$ 437$ million and US\$549 million in the year 2010, commercial banks only availed US\$326 million, resulting in a US\$223 million shortfall to the existing customer base (Vitoria, Mudimu, \&Moyo, 2012). However, the availed US $\$ 326$ million credit is purported to have generated approximately US\$2 billion worth of agricultural output.

Loans to the agricultural sector also comprised only $19 \%$ of the US $\$ 3.8$ billion availed by the banking sector since the adoption of a multi-currency system in 2009 (Farm Mechanization and Conservation Agriculture for Sustainable Intensification (FACASI), 2015). Commercial banks' average agricultural loan portfolios became subdued in the post- land reform period (after the year 1999) compared to the pre and post-independence period (between 1975-1999), as they fell below the $20 \%$ threshold recommended by the Reserve Bank of Zimbabwe (RBZ) (2006, 2016, 2019). Such low financial investments in agriculture by banks are attributed the exposure of the agricultural sector to weather vagaries, low or no collateral by the farmers due to the insecurity of land tenure, market and price risks, political interferences, weak legal systems, and harsh economic conditions in the country (Masiyandima et al. 2011; Nyamutowa and Masunda 2013; Vitoria et al. 2012). Access to agricultural finance is a major stimulus for agricultural development, whose deficiency is a constraint to productivity and income generating opportunities for rural farm households (Qwabe, 2014). The International Finance Corporation (IFC) (2014) underlined the role of agricultural finance in enabling farmers to adopt inputs and technologies that enhance their productivity, income and livelihoods. Financial capital is also required in every step of agricultural operations from land preparation, planting the crop, harvesting, to post-harvest handling, and in establishing start-up agricultural enterprises (Goeringer and Hanson, 2013).

According to Lee et al. (1975), agricultural finance is the economic study of the acquisition and use of capital in agriculture, which deals with the supply and demand for funds. It deals with the financial aspects of a farm business, encompassing both the macro and micro finance aspects of an agricultural economy (Pandey, 2008). According to the IFC (2015), agricultural finance should be perceived as the full range of financial activities involved in getting agricultural products and services through different production phases until they are delivered to the final consumers. In this study agricultural finance is perceived as the provision of diverse financial services like loans, leasing, payment services, savings and crop and livestock insurance by banks for agricultural production, processing and marketing, taking the full view as defined by the IFC (2015). A few studies (Masiyandima, Chigumira and Bara, 2011; Vitoria, Mudimu and Moyo, 2012; FACASI, 2015) have explored the participation of banks in agricultural financing in Zimbabwe. However, there have been a few, if any, updates on the current status of agricultural financing in Zimbabwe, especially under the current economic hardships that the country is facing during austerity measures. This study, therefore, seeks to explore the status of agricultural financing by commercial banks in Zimbabwe, focusing more on the supply of term loans to the sector.

\section{MATERIALS AND METHODS}

The study was underpinned by the pragmatism research philosophy, which advocates for the use of mixed methods in research. Therefore, both quantitative and qualitative techniques were employed in undertaking the study. The study was conducted between August and December 2019 in Harare, the capital city of Zimbabwe where all of the targeted commercial banks' head offices are located. A cross-sectional survey of 12 registered and operating commercial banks in Zimbabwe was done to establish their involvement in agricultural financing, and the magnitude of their participation in terms of total loans that they advance to the sector. Moreover, in light of the general postulation by existing theory that banks are reluctant to lend to the agricultural sector, the study sought to probe the local commercial banks' perceptions on the reasons put forward for that position. Lastly, the study sought to establish the local commercial banks' targeted clientele and the various agricultural financing tools that they offered to them. All 
the 12 commercial banks were targeted as part of the study's sample. A pre-tested structured questionnaire, which was interviewer administered, was used to collect quantitative data. A pre-tested semi-structured interview guide was also used to collect qualitative data for the study. Bank credit officers who worked in the commercial banks' agribusiness units were the targeted respondents for the study. The Statistical Package for Social Sciences (SPSS) Version 26 was used to analyse the quantitative data making use of descriptive statistics, mainly frequencies. On the other hand, NVivo Plus 12 was used to analyse the qualitative data, making use of thematic analysis. Tables and figures were used to present both the quantitative and qualitative findings from the study.

\section{RESULTS AND DISCUSSION}

Out of the 12 targeted bank credit officers, each from the 12 operating registered commercial banks in Zimbabwe, only 8 participated in the questionnaire survey. The study therefore achieved a $67 \%$ response rate. On the other hand, data saturation, a point where no new knowledge was being generated from the interviews (Rodrigues et al., 2017), was reached after interviewing 7 bank credit officers. Consequently, a total of 7 commercial banks participated in oral interviews. However, in spite of scoring a lower questionnaire response rate than desired, the researcher was satisfied with successfully obtaining cooperation from more than half of the operational registered commercial banks in the country. Moreover, the use of interview guides to collect qualitative data for complementing the quantitative data helped the researcher to access richer and in-depth data pertaining to various aspects of interest on the status of agricultural financing in Zimbabwe.

\section{Commercial Banks' Participation in Agricultural Financing in Zimbabwe}

All the 8 commercial banks that participated in the study revealed that they were involved in agricultural financing in Zimbabwe. Several studies (FACASI, 2015; Vitoria et al., 2012) also confirm the participation of most commercial banks in agricultural financing in Zimbabwe. However, these studies revealed that the degree or intensity of participation in agricultural financing is the one that varies across individual banks, an aspect that is addressed in the ensuing sub-section.

\section{Magnitude of Agricultural Financing by Commercial Banks in Zimbabwe}

Actual lending to the agricultural sector differed across individual commercial banks in Zimbabwe according to the findings of this study (Figure 1). Commercial bank 2 (CB2) had the highest agricultural loan portfolio of $60 \%$, whilst CB3 had the least agricultural loan book of $6 \%$. CB1 and CB2's bank credit officers revealed during their oral interviews that agricultural lending formed their largest business portfolios. These findings contradict Vitoria et al. (2012)'s study, which revealed that besides the government owned Agribank that had an agricultural loan book of $83 \%$, all the other commercial banks in Zimbabwe dedicated less than $50 \%$ of their loans to the agricultural sector. However, higher agricultural loan portfolios exhibited by CB2, CB6, and CB8 may be attributed to their intensified participation in government driven credit programs like Command Agriculture. Besides, the timing of the study's data collection exercise coincided with the start of the normal farming season in Zimbabwe (SeptemberOctober) when banks would be disbursing more loans to the agricultural sector.

Figure 1: Commercial Banks’ Agricultural Loan Portfolios

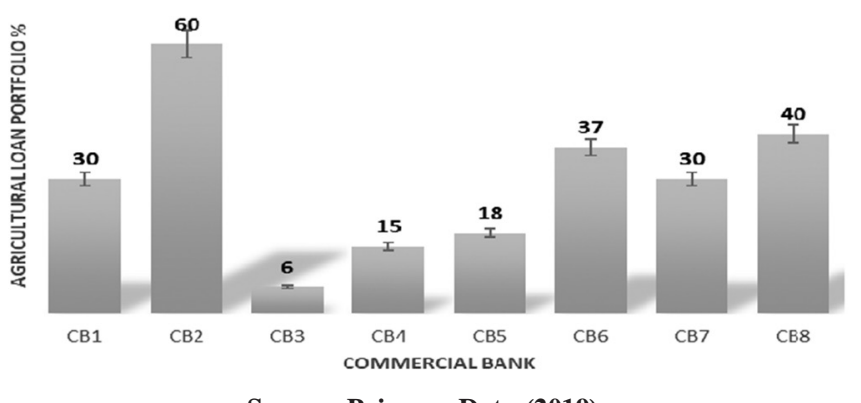

Source: Primary Data (2019)

The average agricultural loan portfolio across the commercial banks translated to $30 \%$, which almost coincided with the average agricultural loan portfolio of $31.69 \%$ reported by the RBZ in its last Quarterly Economic Review of 2019 (RBZ, 2019a). These findings also surpass the average agricultural loan portfolio statistics for local banks presented by the RBZ since the post-land reform period, which mostly ranged below its recommended threshold of $20 \%$ (RBZ, 2006, $2015,2016,2017)$. However, the $30 \%$ average agricultural loan portfolio established in this study is still comparatively lower than the pre-independence period's agricultural loan books for most commercial banks. For example, in 1970 and 1975, commercial banks' average agricultural loan portfolios stood at a higher $47.8 \%$ and $47.3 \%$ respectively (RBZ, 2006). The postindependence agricultural lending, which completely doubled from $26.1 \%$ in 1980 to $55.1 \%$ by 1995 , and trebled to $91.3 \%$ by the year 1999 (RBZ, 2006), also shows that commercial banks were more dedicated to agricultural sector investments. Similar to this study's findings, Masiyandima et al. (2011); Richardson (2005) and Vitoria et al. (2012)'s studies also established that local commercial banks were reluctant to heavily invest in agriculture like they did before the attainment of independence, and before the Fast Track Land Reform (FTLRP) in the year 1999. The commercial banks' demonstrated reluctance to lend to the agricultural sector is addressed in the next section.

\section{Reasons for Low Financial Investments in Agriculture by Commercial Banks in Zimbabwe}

The commercial bank credit officers were asked the extent to which they agreed that several reasons postulated in literature contributed to their banks' relatively lower financial investments in the agricultural sector compared to the preFTLRP period (Table 1). 
Table 1: Reasons for low financial investments in the agricultural sector by commercial banks in Zimbabwe

\begin{tabular}{|c|c|c|c|c|c|}
\hline \multicolumn{6}{|c|}{ Percentage of Banks } \\
\hline Reason & $\begin{array}{l}\text { Strongly } \\
\text { Agree }\end{array}$ & Agree & $\begin{array}{c}\mathrm{n}=8 \\
\text { Neutral }\end{array}$ & Disagree & $\begin{array}{l}\text { Strongly } \\
\text { Disagree }\end{array}$ \\
\hline $\begin{array}{l}\text { Agriculture is too } \\
\text { risky }\end{array}$ & 37.5 & 50 & 0 & 0 & 12.5 \\
\hline $\begin{array}{l}\text { Farmers lack accept- } \\
\text { able collateral }\end{array}$ & 37.5 & 25 & 25 & 12.5 & 0 \\
\hline $\begin{array}{l}\text { Lending rates are } \\
\text { unprofitable }\end{array}$ & 25 & 0 & 0 & 50 & 25 \\
\hline $\begin{array}{l}\text { Mismatch between } \\
\text { deposits received and } \\
\text { loans required }\end{array}$ & 25 & 25 & 0 & 50 & 0 \\
\hline $\begin{array}{l}\text { High transaction costs } \\
\text { of servicing farmers }\end{array}$ & 0 & 25 & 0 & 62.5 & 12.5 \\
\hline
\end{tabular}

Source: Primary Data (2019)

\section{a) Agriculture is too risky}

The majority of the commercial banks (87.5\%) agreed that agriculture was a very risky sector to invest in (Table 1). However, only a few (12.5\%) banks disagreed with this statement. The issue of agricultural sector risk also emerged as a major theme in the study's qualitative data analysis findings (Figure 2). The word risk was mentioned for 13 times by 5 (CB1; CB2; CB3; CB4 and CB5) out of the 7 commercial banks that participated in oral interviews.

Figure 2: Word Cloud of Commercial Banks' Verbatim Responses on why Banks in Zimbabwe are Reluctant to Lend to the Agricultural Sector

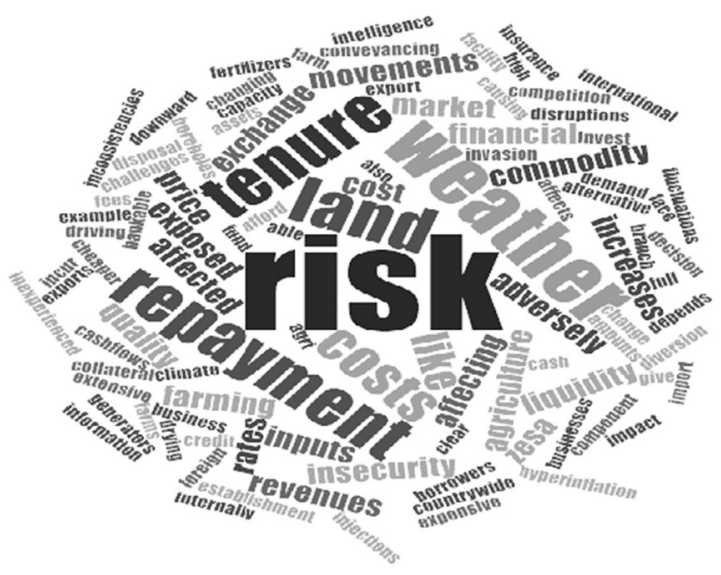

Source: Primary Data (2019)

A text search query for the word risk gave a picture of what the word was linked to in the oral interview discussions with the bank credit officers (Figure 3).
Figure 3: Word tree output for the word "risk"

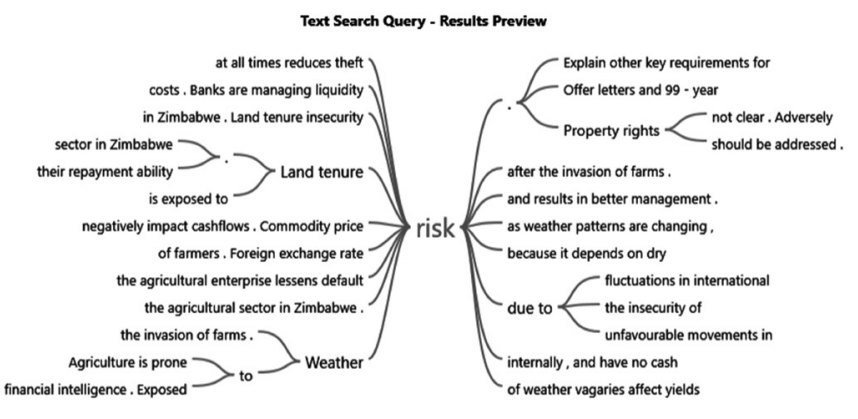

Source: Primary Data (2019)

Land tenure risk was mentioned for 13 times by 5 bank credit officers as a hindrance to the financing of agriculture in Zimbabwe (Figure 3). According to CB1, "Government policy on land tenure exposes the banking sector to risk because a few farmers have 99-year leases and the property rights are totally unclear." These findings are confirmed by Richardson (2005), whose study revealed that former white commercial farmers who possessed secure freehold land titles to their farmland had unparalleled access to bank credit finance before the Fast Track Land Reform compared to the new indigenous farmers. Another study by Mohamed (2003) on smallholder farmers and artisanal fishermen in Zanzibar, Tanzania, also revealed that the lack of title deeds among the farmers accounted for their non-qualification for bank loans as the banks tried to cushion themselves against the land tenure risk.

Weather risk is another key theme that emerged from the study's interviews with the commercial banks' credit officers (Figure 2). The word "weather" was mentioned for 6 times by 5 bank credit officers. The word tree output (Figure 3) shows that commercial banks were reluctant to lend to the agricultural sector because of its exposure to weather risks and vulnerability to the effects of climate change and weather vagaries. According to the bank credit officers, the effect of weather and climate change was worsened by the dependence of most farmers on dryland farming or rain fed agriculture in Zimbabwe. According to CB2, "Vagaries of the weather negatively affect the farmers' yields, cash flows, and their ability to repay loans." CB3 also emphasized that prolonged droughts in Zimbabwe depleted underground water aquifers, the country's key back-up water source for irrigation during drought and low rainfall periods. Similarly, CB4 revealed that most smallholder farmers exposed banks to risk because they were into dryland farming and had no irrigation facilities, which explained why they were excluded from most credit programs (Vitoria, Mudimu and Moyo, 2012; Nyamutowa and Masunda, 2013; United Nations, 2014; Ruete, 2015). The resultant infrequent or seasonal repayment of loans by farmers exposed to such weather risks repelled banks from making financial investments in the sector as shown by this study.

CB2 also mentioned other risk factors of investing in the Zimbabwean agricultural sector like shifts in exchange rates, 
depressed international and local prices, which also negatively affected the farmers' revenues, profits and loan repayment ability (Figure 2). In addition, CB2 revealed that farmers who depended on importing their key production inputs also faced increased production costs from unfavourable movements in exchange rates, equally affecting their revenues and loan repayment capability. These findings are confirmed by the House of Lords European Union Committee (2016), which asserts that farmers, especially smallholders, are vulnerable during low price periods because they lack financial resources to cushion themselves. According to Jainzik and Pospielovsky (2014), such risks attached to output price volatility in agricultural production tend to affect many borrowers at the same time, a scenario that repels financial investors like banks as confirmed by this study. However, some studies contradicts these findings by propagating that not all price variations are problematic to the agricultural sector, but only become so when they are large, cannot be anticipated and do not reflect market fundamentals (FAO et al. 2011). According to Davis (2011) some actors in the agricultural sector actually realize benefits from increased intra-annual food prices, which enable them to recoup their operational costs. The researcher is however yet to come across literature that directly links high commodity price periods with increased bank credit supply to farmers in the developing world context.

Liquidity risk was also discussed as another cause of limited financial investments in agriculture by banks in Zimbabwe (Figure 2). According to CB2, "Depositors have generally lost faith in the banking system as a whole, and are therefore not willing to make long-term deposits that can be advanced to deficit units like agriculture. As a result, banks are competing aggressively for offshore financing, which is in most cases difficult to access because of the negative perceptions facing the country due to political and economic instability after the land reform program." CB2 therefore argued that it may not be a matter of choice that agriculture is not receiving the level of financial investments that it deserves as the pillar of the Zimbabwean economy, but that banks themselves are not liquid enough to lend as much as possible to the sector. Vitoria et al. (2012) confirm that liquidity constraints have affected most banks' agricultural loan books, thus restricting credit to the sector. Similarly, the United Nations (2014) avers that liquidity constraints prevail within the local financial markets, and have resulted in high and uncompetitive interest rates.

\section{b) Local farmers lack acceptable collateral}

The majority $(62.5 \%)$ of the commercial banks under study agreed that they were reluctant to lend to agriculture in Zimbabwe because local farmers lack the acceptable collateral (Table 1). However, $25 \%$ of the banks were neutral whilst $12.5 \%$ disagreed with the statement. This shows that most local commercial banks are reluctant to finance the agricultural sector in Zimbabwe because local farmers lack acceptable collateral. Masiyandima et al. (2011) support these findings by revealing that the land offer letters held by most farmers in Zimbabwe are not recognized as proof of land ownership by commercial banks and cannot be used as collateral for securing borrowing. The same study by Masiyandima et al. (2011) also revealed that the lack of collateral accounts for $60 \%$ of the agricultural loan applications rejected by commercial banks in Zimbabwe, validating further this study's findings. Also supporting these findings, the Inter-Ministerial TaskForce (IMT) Technical Committee (2016), revealed that local banks are still reluctant to lend even to farmers who hold 99 Year Leases because the leases cannot be transferred to third parties in case of default, which makes them unacceptable as collateral. The Ministry of Agriculture (2013) equally avers that local commercial banks gradually withdrew their outreach in rural areas where most farmers reside, citing the main challenge of collateral in the absence of legal title to land. Moreover, Richardson (2005) revealed that the loss of property titles by new farmers in Zimbabwe limited the amount of borrowing and disrupted the banking sector as individuals could no longer pledge their property as collateral for loans. Banks consequently became wary of the possibility of losing their investments (Vitoria et al. 2012) as confirmed by this study. Beyond Zimbabwe, Chandio et al. (2018)'s study in Pakistan also confirms that smallholder farmers in the Sindh Province had limited access to bank credit because they lacked the collateral that was required by the banks.

\section{c) Lending rates are unprofitable}

The majority of the commercial banks $(75 \%)$ disputed that unprofitable lending rates prevented them from making financial investments in the agricultural sector in Zimbabwe (Table 1). This contradicts what has been postulated by some studies in Zimbabwe. For example, Dale (2009) revealed that during the implementation of the Agricultural Sector Productivity Enhancement Facility (ASPEF) program in Zimbabwe, banks were dictated by the government to charge interest at low and unprofitable rates of $20 \%$ per annum when inflation was running at approximately $586 \%$, which repelled most banks from participating in agricultural financing programs. The removal of interest rate ceilings by the RBZ in the Zimbabwean financial system may help to explain the findings of this study because local banks are now at liberty to charge interest rates that they deem profitable for their lending businesses. Moreover, available literature suggests that interest rates charged by banks in Zimbabwe to the agricultural and agribusiness sectors have always been astronomical, prohibitive and only affordable to higher income earners (Vitoria et al. 2012). The United Nations (2014) also confirms that interest rates are high and uncompetitive in Zimbabwe as a result of the shortage of funds in the market. Besides, local banks are also purported to have a limited incentive to focus on the farmers' market, especially smallholders, unless it includes higher risk premiums and greater collateral (Vitoria et al. 2012).

Despite having the majority of the commercial banks disputing that lending to the agricultural sector is unprofitable, it was worthwhile for the study to discuss the minor themes that emerged from the interview discussions with the few banks (25\%) that argued otherwise. Results from the questionnaire 
survey show that 2 banks strongly agreed that lending rates to the agricultural sector in Zimbabwe are unprofitable (CB1 and CB2) (Table 1). Their arguments were centred on the theme of costs, whose word tree output is shown in Figure 4.

Figure 4: Word Tree Output on the emerging theme "Costs"

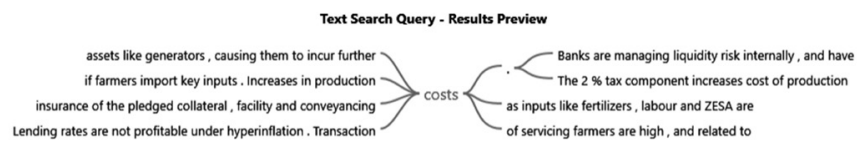

Source: Primary Data (2019)

Both $\mathrm{CB} 1$ and $\mathrm{CB} 2$ bemoaned that under the current hyper inflationary environment in Zimbabwe, profitable interest rates on loans charged today could easily become totally unprofitable tomorrow. Therefore, the two banks argued that it could be wiser for a bank to withhold making financial investments in the agricultural sector until economic stability is restored in the country. The issue of costs was initially discussed from the demand side (the farmer's side). According to $\mathrm{CB} 1$, "Over and above the financing costs like establishment fees, insurance costs of the pledged collateral, facility costs and conveyancing costs, $2 \%$ tax is also charged on all transfers as part of the government's current austerity measures." All these costs, according CB1, were deducted upfront from the loan amounts applied for by the farmers. Therefore, given the small loan amounts that the majority of famers usually sought from banks, they were left with little funds that could not make any meaningful returns when injected into their agricultural enterprises. CB1 ultimately stressed that it was not viable at the onset for the bank to lend to the farmers under such a scenario.

On the other hand, CB2 highlighted that, "Farmers are currently facing increases in seed, fertilizer, chemical, labor and utility costs like electricity and water under the prevailing hyperinflation in the country." These high costs were argued to make their agricultural enterprises less profitable, which also negatively affected their ability to repay loans. CB2 also discussed the effects of disruptions in utilities like electricity and water, which forced farmers to incur further costs by making unplanned alternative investments in solar, generators and irrigation equipment. As a result, the farmers' returns on financed projects were reduced or completely eroded. This was also purported to negatively affect their ability to repay the advanced loans. Hence, the bank argued that it was wiser for banks to withhold the financing of agricultural projects under such circumstances. These arguments by the banks showed that the increased costs faced by farmers negatively affected their income generating capacity, which also negatively affected their loan repayment ability. Mayowa (2015) and Odu et al. (2010)'s studies in South Africa and Ghana respectively, confirm that high income from farming activities is preferred by banking institutions because it acts as a guarantee/ assurance that a farmer would be able to timeously repay the loan. d) Mismatch between deposits received and loans required

Pertaining to the presence of a mismatch between the short-term nature of deposits received by banks and the longterm nature of loans sought by agricultural sector clients as postulated by some studies in Zimbabwe, 50\% of the banks agreed, whilst the other 50\% disagreed (Table 1). Since half of the banks agreed that the tenure mismatch between deposits received and the loan amounts required by farmers prevented them from making extensive investments in the agricultural sector, this study recognised it as a barrier to agricultural financing by commercial banks in Zimbabwe. The Ministry of Agriculture (2013) agrees that the Zimbabwean banking sector is not able to lend to agriculture because it can only avail short-term tenure loans of less than 30 days, which are not suitable for agricultural sector needs, because $93 \%$ of the deposits it receives are subject to quick withdrawal (demand 60\%; short-term 20\%; savings 5\% and long term 7\%). Vitoria et al. (2012) correspondingly underscore that deposits in the Zimbabwean banking sector are short term and volatile in nature because approximately $90 \%$ of them relate to salary payments, thereby making it difficult for the banks to provide the longer-term finance needed for infrastructural development, leasing, recapitalization and expansion projects in sectors like agriculture without creating a serious funding mismatch. Hence, Zimbabwean commercial banks are reluctant to lend to the agriculture because they have no capacity to fulfil the sector's longer-term financing needs due to the short-term nature of deposits that they also receive.

\section{e) High transaction costs of servicing farmers}

The majority of the banks (75\%) disagreed that high transaction costs deterred them from serving the agricultural sector in Zimbabwe (Table 1), whilst only a minority (25\%) agreed. Hence, the study established that high transaction costs of servicing farmers do not contribute to local commercial banks' low financial investments in the agricultural sector in Zimbabwe. These findings contradict most of the available literature. According to Ruete (2015), the geographically dispersed distribution of farmers in rural areas is a repelling factor to financing by banks. Quartey et al. (2012) also confirm that many agricultural households are located in remote parts of the country and are often widely dispersed and inaccessible. This purportedly makes it difficult for financial institutions to provide cost-effective and affordable services due to higher costs of processing and servicing their unsecured small loans as postulated by Yaron (1992). Likewise, Kirui et al. (2010) confirm that the geographical dispersion of farmers and their poor organization make their monitoring costly to lenders, hence their reluctance to serve them. CB2, one of the two banks that agreed with the fact that high transaction costs of serving farmers prevented it from heavily investing in the agricultural sector in Zimbabwe, expounded that this was hinged on the problem of lack of capacity on the part of the bank. Lack of capacity pertained to the bank's inability to establish branches countrywide because of the increased overheads involved (rent, staff costs, utilities among others). Hence, the transaction costs of servicing the farmers, 
especially in sparsely populated rural areas, outweighed the returns that the bank could realize from serving them. CB2 further revealed that lack of capacity issues explained why the bank closed its branches in most rural parts of the country where it used to operate serving farmers before the FTLRP.

\section{Alternative Agricultural Financing Tools Offered by Zimbabwean Commercial Banks}

The findings presented in Table 2 show that 7 out of 8 commercial banks under study offered value chain, invoice financing, and overdraft facilities to the agricultural sector in Zimbabwe. Available literature confirms that value chain financing, particularly contract farming, is popular in Zimbabwe as banks attempt to manage around the land tenure and collateral risks associated with financing local farmers directly (Winn et al. 2009). Confirming the dominance of value chain financing in the Zimbabwean banking sector, Vitoria et al. (2012) also revealed that out of the US\$326 million bank credit supplied by banks in the year 2010, 70\% was supplied to 300 000-350 000 smallholder contract farmers of cotton and tobacco. The Zimbabwe Agricultural Development Trust (ZADT) (2017), which funds smallholder farming in Zimbabwe through the Credit for Agricultural Trade and Expansion (CREATE) fund that is mobilized through 13 financial institutions ( 8 banks and 5 Micro Finance Institutions (MFIs)), also reported that the majority of smallholder farmers accessed funding under its programs through value chain actors.

Table 2: Agricultural Financing Tools Offered by Commercial Banks in Zimbabwe

\begin{tabular}{lc}
\hline Type of Financing & $\begin{array}{c}\text { Number of Commercial Banks Offering } \\
\mathrm{n}=8\end{array}$ \\
\hline Value chain finance & 7 \\
Invoice finance & 7 \\
Overdraft facilities & 7 \\
Term loans & 6 \\
Warehouse receipts & 5 \\
Insurance & 5 \\
Leasing & 2 \\
Pre- and post-shipment finance & 1 \\
Letters of credit & 1 \\
\hline
\end{tabular}

Source: Primary Data (2019)

Invoice financing was also offered by 7 out of the 8 commercial banks that participated in the study (Table 2). The commercial banks explained that there was less default risk involved in invoice financing because the farmers would be borrowing to meet incidental expenses against already realized income (from already sold agricultural produce as evidenced by the invoice), but awaiting payment. Onumah and Meijerink (2011) confirm that invoice financing is sought by borrowers to ease their short-term liquidity constraints or cashflow problems. According to the commercial banks, the proceeds due from the financed invoices, which would be paid through the lending bank, acted as security to the lender. Miller and Jones (2010), who call this type of financing "receivables financing", confirm that its security is provided by the payment of the sales proceeds directly to the lender. A study by Vitoria et al. (2012) confirmed the availability of invoice financing in Zimbabwe in NMB Bank, which targeted Model A2 commercial farmers, who practiced horticulture and livestock farming, as well as seed houses and processors.

Overdraft facilities were also offered by 7 out of the 8 commercial banks under study (Table 2). The banks revealed that they offered overdraft facilities to large corporates and loyal highly collateralized customers in the agricultural sector, mostly large-scale commercial farmers. In support of these findings, Masiyandima et al. (2011)'s study revealed that the Zimbabwean money market could only raise short-term loans like overdrafts for working capital and seasonal cropping in the agricultural sector. Vitoria et al. (2012) also confirms that overdraft facilities were offered by banks like NMB, Metbank, MBCA (now Nedbank) and Ecobank to the agricultural sector in Zimbabwe. However, the study revealed further that the financing facility was reserved for established agro-processing firms like Northern Tobacco, Natfoods and Delta Corporation among others; as well as longstanding customers, Model A2 tobacco farmers, and farmers in the horticulture sector. FACASI (2015) also confirms that 30-day overdraft facilities were reserved for executive clients who banked large amounts of money with banks like CABS and Agribank.

Term loans were offered by 6 out of the 8 commercial banks that participated in this study (Table 2). According to FACASI (2015), banks like CBZ, MBCA, Agribank, and ZB Bank offered term loans through their agribusiness units, targeting farmers with title deeds or lease agreements. This shows that smaller farmers were excluded from accessing the term loans. Warehouse receipts were also offered by 5 out of 8 commercial banks under study (Table 2). The popularity of warehouse receipts may be explained by the fact that they lessen risk to the lender because the farmer's stored/ warehoused produce (for example, maize and wheat) awaiting selling are taken over by the lender as collateral (Ruete, 2015).

The study also established that 5 out of the 8 commercial banks offered agricultural insurance to farmers in Zimbabwe (Table 2). According to the banks that offered agricultural insurance (both crop and livestock insurance), insurance was compulsory for all of its borrowers to ensure that in case of unforeseen circumstances, all financial investments in specific agricultural projects were recuperated. Insurance therefore safeguarded both the bank and the farmers' investments. However, due to the current hyperinflationary environment in Zimbabwe, concerns were raised by the banks over the costly insurance premiums borne by the farmers, and the ability of the recuperated financial investments from insurance to fully cover the advanced loans and other investments that would have been lost during the unforeseen disasters. The absence of agricultural insurance in some banks may be explained by the dominance of value chain financing in the banking sector, which in itself acts as an insurance mechanism that minimizes the banks' exposure to risks associated with lending directly to individual farmers (Ruete, 2015). This trend was observed in this study as the three banks (CB2; CB3 and CB7) that did not offer any agricultural insurance were actively involved in value chain financing with large corporates like Norton Leaf Tobacco, Tongaat Hullet, Tanganda, NatFoods, Delta 
Beverages, Schweppes and Tianze Tobacco among other big contracting companies in Zimbabwe. These commercial banks stressed that they did not lend directly to individual farmers because of the risks involved.

Leasing was offered to the agricultural sector by only 2 commercial banks in the study (Table 2). CB2 and CB4 highlighted that they offered lease financing for agricultural equipment to local farmers. Vitoria et al. (2012)'s study confirms these findings by avowing the collapse of lease financing in Zimbabwe due to the changes in the economy and the agricultural sector after the FTLRP. However, as revealed further by Vitoria et al. (2012), lease financing is re-emerging as some banks are now offering it in the Zimbabwean banking sector as shown by this study. Only one bank offered pre-and post-shipment finance (Table 2). According to CB2, Pre and Post Shipment finance was mostly offered to tobacco merchants and tea industries that contracted various individual farmers, who were also into exports. CB2 expounded that this agricultural financing tool was two- legged. Firstly, Pre-Shipment finance was offered for the growing and processing of export products like tea and tobacco locally. The Post-Shipment leg subsequently provided bridging finance to the contractors after they had exported their produce awaiting payment from their offshore customers. Hence, it is a variation of invoice financing that was reserved for cash crop farming companies that were into exporting.

CB6 is the only bank under study that offered Letters of Credit to its agricultural sector clients (Table 2). In this case, the bank guaranteed a supplier from which a farmer was accessing credit purchases that their payment would be received in full and on time. In case of default by the farmer, the bank acted as a guarantor by settling the remaining or entire amount in full. On the other hand, CB3 revealed that it offered another interesting and innovative asset financing tool for farmers termed "Contract Based Asset Finance". It differed from the traditional long-term Capital Expenditure (CAPEX) loans in that it was only reserved for farmers who had already secured contract farming arrangements with large contractors/ value chain actors.

\section{Loan Tenures Sought from Banks vs Loan Tenures Offered to Farmers in Zimbabwe}

Figure 5 shows the loan tenures that the commercial banks revealed were sought by most farmers in Zimbabwe, versus the tenures that they actually offered them.

Figure 5: Loan tenures sought by farmers vs loan tenures offered by commercial banks in Zimbabwe

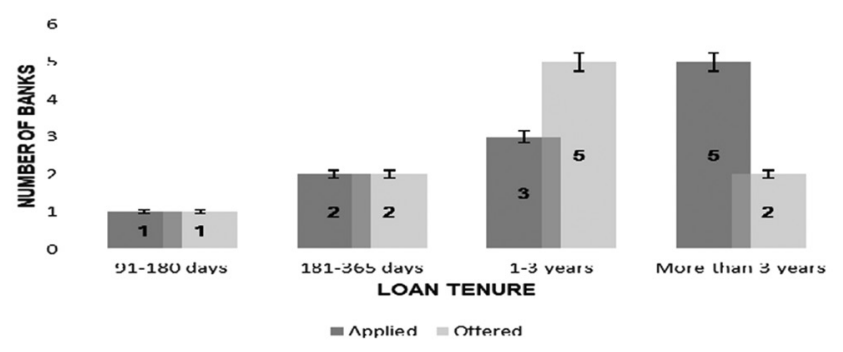

Source: Primary Data (2019)
Only one bank (CB8) revealed that farmers applied for shortto-medium term loans of 91-180-days tenure, and fully met the demand for those loans as shown in Figure 5. Two banks (CB1 and CB3) also revealed that agricultural sector clients sought medium-term loans of 181-365-days tenure. The same banks also highlighted that they also offered these medium-term loans to their agricultural sector clients, thereby meeting their demand (Figure 5). Based on these findings, the study established that there was a match between the demand and supply of short to medium-term agricultural loans in the Zimbabwean banking system. However, Vitoria et al. (2012)'s study contradicts these results because it claimed that the 270-day term loans' availability is limited in the Zimbabwean banking sector.

The results presented in Figure 5 also show that medium to long-term loans of 1-3 years were sought in 3 of the 8 commercial banks under study, whilst a total of 5 out of the 8 commercial banks offered them to agricultural sector clients. Supply actually seemed to be outstripping the demand for these medium-term loans, which may point to lack of awareness among local farmers on the term loan packages being offered by local commercial banks. On the other hand, long-term loans of more than 3 years were sought from 5 of the 8 commercial banks under study, whilst only 2 banks offered them to the farmers as shown in Figure 5. According to CB1, long-term loans sought by the majority of the farmers were mostly asset finance and capital expenditure (CAPEX) loans. CB1 also revealed that the scarcity of CAPEX loans was caused by the lack of property rights among farmers in the agricultural sector in Zimbabwe to secure borrowing, confirming findings presented earlier in the study. The bank however expounded that such long-term loans could only be advanced to farmers if they were secured by off-farm collateral. The study therefore established that there was a mismatch between the demand and supply of long-term agricultural production loans in the Zimbabwean banking system as confirmed by various studies (Ministry of Agriculture, 2013; Vitoria et al. 2012)

\section{Approval Status of the Majority of Agricultural Loan Applications by Farmers in Zimbabwe}

Table 3 shows the loan approval status of the majority of the agricultural loan applications received by commercial banks that participated in this study. The commercial banks were asked if the agricultural loan applications that they received from farmers in Zimbabwe were mostly fully approved, partially approved or completely rejected, to which they respondent with yes/ no responses as shown below.

Table 3: Loan approval status of most agricultural production loan applications received by commercial banks in Zimbabwe

\begin{tabular}{lcc}
\hline & & $\mathrm{n}=8$ \\
Loan Approval Status & Yes & No \\
\hline Fully approved & 7 & 1 \\
Partially approved & 1 & 7 \\
Rejected & 2 & 6 \\
\hline
\end{tabular}

Source: Primary Data (2019) 
The bulk of the agricultural sector loan applications were fully approved as confirmed by 7 out of the 8 commercial banks under study (Table 3). These results contradict Masiyandima et al. (2011), whose study revealed that the bulk of agricultural sector loan applications were rejected due to various reasons like lack of collateral, lack of own contribution, poor past performance and poor past loan record among others. According to CB1, "At the first stage of loan application, a farmer receives the list of requirements for eligibility. Farmers who fail to meet the requirements are already screened out at this initial stage." This explains why banks under study rejected a few loan applications as most of the farmers who reached the application submission stage would have met most of the loan requirements. On the other hand, CB4 expounded that, "Rejecting most loans would imply that the bank is targeting clients that are out of its risk appetite. Hence, its sourcing strategy is aligned to clients that are within its risk appetite, who are able to satisfy most of its lending requirements." CB6 also confirmed that the final stages of the loan application process were reached by applicants who would have already gone through a thorough screening process. However, in agreement with Masiyandima et al. (2011), CB6 indicated that most loan applications fell along the way on the grounds of lack of collateral. According to the bank, this explained why it mostly scores a $98 \%$ success rate for the agricultural loan applications it receives. Only 2 banks (CB2 and CB3) highlighted that the bulk of the agricultural loan applications they received from individual farmers were completely rejected because they preferred to lend through well-established and highly collateralized value chain actors to lessen its exposure to default risk.

\section{Zimbabwean Commercial Banks' Target Clientele}

Figure 6 shows the clientele targeted by the commercial banks that participated in this study.

Figure 6: Clientele targeted by commercial banks in Zimbabwe

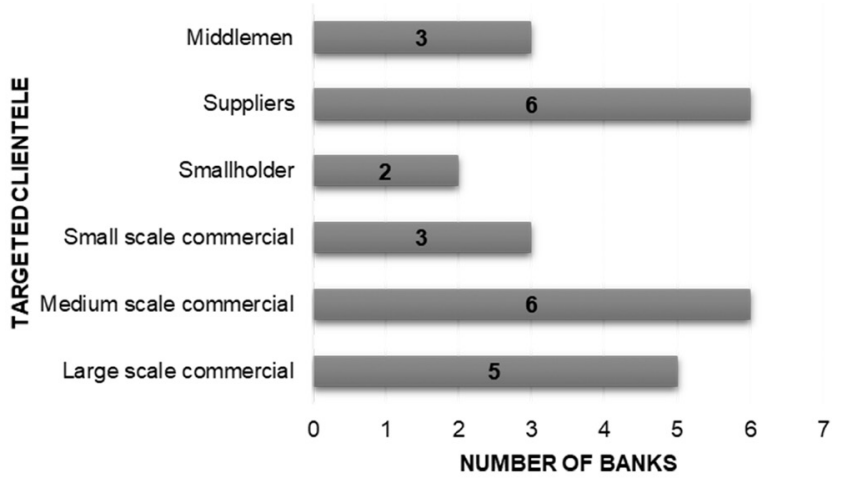

Source: Primary Data (2019)

The commercial banks under study mostly served suppliers and medium scale commercial farmers, who were targeted by 6 out of the 8 commercial banks (Figure 6). Suppliers were engaged with the commercial banks through value chain financing arrangements previously discussed in this study.
Large scale commercial farmers were also a popular clientele among the commercial banks, who were served by 4 out of the 8 commercial banks under study (Figure 6). Their popularity may be attributed to the fact that most of them are highly collateralized, a scenario that shields banks from exposure to risk in case of default. As mentioned elsewhere in this study, Vitoria et al. (2012) confirm that most long-term financing tools for the agricultural sector are reserved for highly collateralized large farmers and agribusinesses. On the other hand, middlemen were served by only 3 commercial banks that participated in the study (Figure 6). CB4 explained that the middlemen clientele it served organized out-grower schemes through which they bought agricultural produce from individual farmers, stored, and sold it to different markets. According to the bank, the middlemen acted as mediators between individual farmers and the final market.

Small scale commercial farmers were also served by 3 out of 8 commercial banks that participated in the study (Figure 6). However, the least popular clientele were the smallholder farmers, who were served by only 2 out of the 8 commercial banks. These findings are confirmed by FACASI (2015), which claims that the majority of small scale farmers in Zimbabwe are excluded from bank lending programs because they are not formally employed, and do not have documents like pay slips that are required to process loans. In addition, they are purported to lack financial records for their business operations and cannot prove the viability of their farming activities, thereby contributing to their inability to access bank loans as shown by this study (FACASI, 2015). Yaron (1992), in support, also underscores that where commercial lending institutions have been active in rural areas, they prefer to serve large scale farmers, and totally ignore smallholder farmers.

\section{CONCLUSION}

The study aimed to establish the status of agricultural financing by commercial banks in Zimbabwe. All commercial banks under study participated in agricultural financing. However, the magnitude of actual financial investments in agriculture varied across banks. Average agricultural loan portfolios were higher than the majority of the statistics reported after the year 2000 by the RBZ and other available studies. However, current agricultural loan books are still lower than the pre- land reform maximum achieved in 1999. Low investments in agriculture by local commercial banks were attributed to land tenure and weather risks, as well as lack of collateral among farmers. The hyper-inflationary environment in Zimbabwe also increased the farmers' costs of production, thereby affecting their ability to repay loans. Value chain financing, bank overdrafts, invoice finance, warehouse receipts and term loans were the most popular agricultural financing tools offered by commercial banks in the Zimbabwean banking sector. There seemed to be an excess supply of medium to long-term loans by the commercial banks, as few farmers sought them. However, the demand for longer-term loans for capital expenditure remained unmet. Most agricultural loan applications were fully approved by the 
commercial banks under study. However, the lack of collateral hindered most farmers from completing the loan application process. The commercial banks' preferred clientele included suppliers, medium and large-scale commercial farmers. Small scale and smallholder farmers were excluded from financing programs by the majority of the commercial banks.

Therefore, policy should address the issues surrounding land tenure in Zimbabwe because land tenure risk is the key obstacle to agricultural financing by local commercial banks. Irrigation infrastructure development should also be prioritized to eliminate the dependence by farmers on the risky rain-fed agriculture, which repels financial investments by commercial banks. Commercial banks should strive to match their financing packages with the actual needs of the farmers on the ground, for example, by providing more long-term loans to the sector. Value chain actors should be monitored to ensure that they do not charge exorbitant rates to farmers to ensure the growth and perpetuity of their agricultural enterprises in the long-term. Moreover, educational campaigns to local farmers should be intensified to improve their awareness of alternative financing tools that they can access from the financial institutions. Farmers are also implored to invest in off-farm collateral in the absence of legal titles to their land in line with what the banks want to ensure their improved access to bank credit. They should also strive to invest in cheaper irrigation infrastructure like boreholes and drip irrigation kits to lessen their exposure to weather vagaries like drought. Investments in irrigation infrastructure will also ensure agricultural production all year round, and thus improve the farmers' performance and ability to access further financing.

\section{REFERENCES}

Adelman, I. (2001) 'Fallacies in Development Theory', in Frontiers of Development Economics: The Future In Perspective, pp. 103-133. Available at: http://documents.worldbank.org/curated/en/586861468762924370/pdf/multi0page.pdf\#page $=115$ (Accessed: 10 October 2018).

Alliance for Green Revolution in Africa (AGRA). (2017) 'Africa Agriculture Status Report: The Business of Smallholder Agriculture in Sub-Saharan Africa', Alliance for a Green Revolution in Africa (AGRA, (5), p. 180 PP. doi: http://hdl.handle. net/10568/42343.

Alliance for Green Revolution in Africa (AGRA). (2018) 'Impact: Towards Africa's Agricultural Transformation', p. 48. Available at: https://agra.org/wp-content/uploads/2018/02/ IMPACT-Edition-1-January-March-2018-2.pdf (Accessed: 26 September 2018).

Anríquez, G. and Stamoulis, K. (2007) Rural Development and Poverty Reduction : Is Agriculture Still the Key ?, ESA Working Paper/ Agricultural and Development Economics Division, FAO. 07. Available at: www.fao.org/es/esa (Accessed: 10 October 2018).
Chandio, A. A. et al. (2018) 'Effects of agricultural credit on wheat productivity of small farms in Sindh, Pakistan: Are short-term loans better?', Agricultural Finance Review, 78(5), pp. 592-610. doi: 10.1108/AFR-02-2017-0010.

Dale, D. (2009) The Recovery and Transformation of Zimbabwe's Communal Areas, Comprehensive Economic Recovery in Zimbabwe. Available at: http://archive.kubatana.net/docs/ demgg/undp_recovery_of_zim\%27s_commun_090724.pdf (Accessed: 1 April 2019).

Davis, J. (2011) 'Agricultural price volatility and its impact on government and farmers: a few observations', in OECD Agricultural Price Volatilities Conference:G20 Outreach, pp. 1-18. Available at: https://www.oecd.org/swac/events/48215044.pdf (Accessed: 25 January 2019).

Diao, X., Hazell, P. and Thurlow, J. (2010) 'The Role of Agriculture in African Development', World Development, 38(10), pp. 1375-1383. doi: 10.1016/j.worlddev.2009.06.011.

FACASI. (2015) 'Financial Products for Farmers and Service Report'. Available at: http://facasi.act-africa.org/file/20160125_ financial_products_for_farmers_and_service_providers_report_zimbabwe.pdf (Accessed: 17 September 2018).

Fan, S. et al. (2013) 'From Subsistence to Profit; Transforming Smallholder Farms', International Food Policy Research Institute, pp. 1-30. doi: 10.1016/j.euromechsol.2011.01.004.

FAO [Food and Agriculture Organisation] et al. (2011) Price volatility in agricultural markets: policy responses. Available at: http://www.fao.org/fileadmin/templates/est/Volatility/Interagency_Report_to_the_G20_on_Food_Price_Volatility.pdf (Accessed: 25 January 2019).

Goeringer, P. and Hanson, J. (2013) 'Review of Lender Requirements for Beginning Farmer Loan Products'. Available at: https://drum.lib.umd.edu/bitstream/handle/1903/15007/Credit Fact Sheet.pdf?sequence=1 (Accessed: 28 February 2019).

House of Lords EU Committee. (2016) 'Responding to price volatility : creating a more resilient agricultural sector'. Available at: http://www.parliament.uk/hleu. (Accessed: 25 January 2019).

Huang, J. and Ma, H. (2010) 'Capital Formation and Agriculture Development in China'. Rome. Available at: http://www. fao.org/fileadmin/templates/tci/pdf/CapitalFromation/China Capital_Formation_and_Agriculture_Growth_in_China_22_ Aug_2010_clean_copy.pdf (Accessed: 5 October 2018).

Inter-Ministerial Task-Force (IMT) Technical Committee. (2016) 'Ministry of Lands \& Rural Resettlement Bankers Conference on the 99 Year Lease'. Available at: http://www. justice.gov.zw/imt/wp-content/uploads/2017/10/99-YEARLEASE-BANKERS-CONFERENCE-REPORT-MOLRR8-APRIL-2016.pdf (Accessed: 25 September 2018). 
International Finance Corporation. (2014) 'Access to Finance for Smallholder Farmers: Learning from the Experiences of Microfinance Institutions in Latin America'. Available at: www.ifc.org (Accessed: 17 September 2018).

International Finance Corporation (IFC). (2015) 'Agricultural Lending: A How-To Guide'. Vietnam. Available at: https://www.ifc.org/wps/wcm/connect/88d4a7004a42ef7c800f bb10cc70d6a1/Agricultural+Lending-A+How+To+Guide. pdf?MOD=AJPERES (Accessed: 10 October 2018).

Jainzik, M. and Pospielovsky, A. (2014) 'Busting agro-lending myths and back to banking basics: A case study of accessbank's agricultural lending', in Finance for Food: Towards New Agricultural and Rural Finance, pp. 115-135. doi: 10.1007/978-3642-54034-9 9.

Kirui, O. K., Okello, J. J. and Nyikal, R. A. (2010) 'Awareness and use of $\mathrm{m}$-banking services in agriculture: The case of smallholder farmers in Kenya.', in Paper presented at African Association of Agricultural Economists Conference, pp. 1-18. doi: 10.4018/978-1-60566-820-8.ch001.

Lee, W. et al. (1975) 'Agricultural Finance', American Journal of Agricultural Economics, 57(3), p. 528. doi: 10.2307/1238423.

Makina, D. (2010) 'Historical perspective on Zimbabwe's economic performance: A tale of five lost decades', Journal of Developing Societies, 26(1), pp. 99-123. doi: 10.1177/0169796X1002600105.

Masiyandima, N., Chigumira, G. and Bara, A. (2011) Sustainable Financing Options for Agriculture in Zimbabwe.

Mayowa, B. T. (2015) 'Determinants of Agricultural Credit Acquisition From the Land Bank of South Africa: A case study of smallholder farmers in peri-urban areas of Mopani District, Limpopo Province, South Africa'. Available at: http:// ulspace.ul.ac.za/bitstream/handle/10386/1730/braide_tm_2015. pdf? sequence $=1 \&$ isAllowed $=y$ (Accessed: 10 March 2019).

Miller, C. and Jones, L. (2010) 'Value Chain Finance. Tools and Lessons'. Food and Agriculture Organization of the United Nations and Practical Action Publishing.

Ministry of Agriculture. (2013) 'Zimbabwe Agriculture Investment Plan (ZAIP): A comprehensive framework for the development of Zimbabwe's agriculture sector.', pp. 1-131. Available at: http://extwprlegs1.fao.org/docs/pdf/zim152671.pdf (Accessed: 30 November 2018).

Mohamed, K. (2003) 'Access to Formal and Quasi-Formal Credit by Smallholder Farmers and Artisanal Fishermen: A Case of Zanzibar', Research on Poverty Alleviation, (03.6). Available at: http://www.repoa.or.tz/documents/03.6_-_Mohamed_.pdf (Accessed: 7 February 2019).
Nyamutowa, C. and Masunda, S. (2013) 'An Analysis of Credit Risk Management Practices in Commercial Banking Institutions in Zimbabwe', International Journal of Economic Research, v4i1(2229-6156), pp. 31-46. Available at: www.ijeronline.com (Accessed: 18 September 2018).

Odu, O. . et al. (2010) 'Determinants of Rice Farmer' s Access to Credit in Niger State , Nigeria', Journal of Rural Economics and Development, 20(1), pp. 8-20. Available at: https://ageconsearch.umn.edu/bitstream/206865/2/Odu.pdf (Accessed: 8 March 2019).

Onumah, G. and Meijerink, G. (2011) 'Innovative Agricultural Financing Models', Esfim, (6), pp. 1-6.

Pandey, U. K. (2008) 'Agricultural Cooperation, Finance and Business Management', pp. 1-30.

Peter Timmer, C. (1988) 'The agricultural transformation', Handbook of Development Economics. Elsevier, pp. 275-331. doi: 10.1016/S1573-4471(88)01011-3.

Reserve Bank of Zimbabwe. (2019). Quarterly Economic Review. Available at: https://www.rbz.co.zw/documents/quarterly_review/qerjune2014.pdf (Accessed: 25 March 2019).

Quartey, P. et al. (2012) 'Agricultural Financing and Credit Constraints The Role of Middlemen in Marketing and Credit Outcomes in Ghana INSTITUTE OF STATISTICAL, SOCIAL \& ECONOMIC RESEARCH (ISSER) IGC PROJECT ON AGRICULTURAL FINANCING AND CREDIT CONSTRAINTS: THE ROLE OF MIDDLEMEN'. Available at: https://www.theigc.org/wp-content/uploads/2014/09/QuarteyEt-Al-2012-Working-Paper.pdf (Accessed: 4 February 2019).

Qwabe, N. (2014) 'Lending to small-scale farmers in South Africa: A case for best practices in formal institutions'. Available at: https://repository.up.ac.za/bitstream/handle/2263/43227/ Qwabe_Lending_2014.pdf?sequence=1 (Accessed: 25 January 2019).

Reserve Bank of Zimbabwe. (2015) Monetary Policy Statement, Monetary Policy Statement. Available at: http://www.rbz. co.zw/assets/monetary-policy-statement-january-2015-2---(2). pdf (Accessed: 17 September 2018).

Reserve Bank of Zimbabwe. (2016) Monetary Policy Statement, Monetary Policy Statement. Available at: https://www. rbz.co.zw/assets/monetary-policy-statement-january-2016.pdf (Accessed: 17 September 2018).

Reserve Bank of Zimbabwe. (RBZ) (2006) Sustainable Financing of Agriculture. Available at: http://www.rbz.co.zw/assets/ supplement2.pdf (Accessed: 10 October 2018).

Reserve Bank of Zimbabwe (RBZ) (2017) Monthly Economic Review. 
Reserve Bank of Zimbabwe (RBZ) (2018) Monthly Economic Review.

Reserve Bank of Zimbabwe (RBZ) (2019a) December Quarterly Economic Review.

Reserve Bank of Zimbabwe (RBZ) (2019b) Monthly Economic Review.

Richardson, C. J. (2005) 'The loss of property rights and the collapse of Zimbabwe', Cato Journal, 25(3). Available at: https://sarpn.org/documents/d0001190/P1320-property_rights_ Zimbabwe_Richardson2.pdf (Accessed: 17 September 2018).

Rodrigues, I. B. et al. (2017) 'Development and validation of a new tool to measure the facilitators, barriers and preferences to exercise in people with osteoporosis', BMC Musculoskeletal Disorders. BMC Musculoskeletal Disorders, 18(1), pp. 1-9. doi: 10.1186/s12891-017-1914-5.

Ruete, M. (2015) 'Financing for Agriculture: How to boost opportunities in developing countries INVESTMENT IN AGRICULTURE Policy Brief \#3', pp. 1-13.

United Nations (2014) Zimbabwe country analysis working document final draft. doi: http://dx.doi.org/10.1093/ehjci/jev278.

Vitoria, B., Mudimu, G. and Moyo, T. (2012) 'Status of Agricultural and Rural Finance in Zimbabwe', FinMark Trust, (July). Available at: http://www.finmark.org.za/wp-content/ uploads/2016/01/Rep_Status-of-RAFin_Zim.pdf (Accessed: 15 September 2018).

Winn, M, Miller, C. and Gegenbauer, I. (2009) 'The use of Structured Finance instruments in agriculture in Eastern Europe and Central Asia'. Available at: http://www.fao.org/3/ ap294e/ap294e.pdf.

World Bank. (2015) 'Enabling the Business of Agriculture 2015'. doi: 10.1596/978-1-4648-1021-3.

Yaron, J. (1992) 'Rural finance in developing countries', World Bank Discussion Paper 150., p. 14. doi: August, 2015.

Zimbabwe Agricultural Development Trust (ZADT) (2017) Annual Report. 